Jurnal Basicedu Volume 3 Nomor 4 Tahun 2019 Halaman 2071-2082

JURNAL BASICEDU

Research \& Learning in Elementary Education

https://jbasic.org/index.php/basicedu

\title{
PENGEMBANGAN E-LEARNING MATA KULIAH PEMBELAJARAN MATEMATIKA SD BERBASIS APLIKASI MOODLE DI PGSD
}

\author{
Akmal Rijal $^{1}$, Andriana Sofiarini ${ }^{2}$ \\ STKIP PGRI Lubuklinggau, Sumatera Selatan, Indonesia ${ }^{1,2}$ \\ Email : akmalrijal3@gmail.com ${ }^{1}$, andrianasofiarini@stkippgri-lubuklinggau@ac.id ${ }^{2}$
}

\begin{abstract}
Abstrak
Terbatasnya waktu perkuliahan di kelas terkadang menghalangi para dosen dalam memberikan semua materi perkuliahan, kesulitan ini banyak dikeluhkan oleh mahasiswa. Untuk itu dikembangkan e-learning mata kuliah pembelajaran matematika SD berbasis aplikasi moodle yang dapat memberikan pengalaman belajar bagi mahasiswa sebagai aktualisasi dari student centered learning. Tujuan penelitian ini adalah menghasilkan e-learning mata kuliah pembelajaran matematika SD berbasis aplikasi moodle di program studi PGSD yang valid, praktis, dan efektif. Jenis penelitian yang digunakan adalah penelitian pengembangan dengan model pengembangan Plomp, yang terdiri dari tiga tahapan yaitu: preliminary research, prototyping phase, dan assesment phase. Data penelitian diperoleh dari uji validitas, praktikalitas, dan efektivitas. Data uji validitas diperoleh melalui lembar validasi. Data kepraktisan diperoleh dari lembar angket respon mahasiswa, dan wawancara. Data keefektifan dilihat dari aktivitas dan hasil belajar mahasiswa. Hasil penelitian menunjukkan bahwa e-learning yang dikembangkan memenuhi kriteria valid dari segi isi dan konstruk dengan nilai ratarata 95\%. E-learning sudah praktis baik dari segi keterlaksanaan, kemudahan, dan waktu yang diperlukan dengan rata-rata nilai 92,5\%. E-learning juga telah efektif dari segi aktivitas dan hasil belajar mahasiswa dengan nilai rata-rata aktivitas $81,2 \%$ dan hasil belajar dengan tingkat ketuntasan $87,5 \%$. Berdasarkan hasil tersebut dapat disimpulkan bahwa e-learning yang dikembangkan dapat dinyatakan valid, praktis, dan efektif.
\end{abstract}

Kata Kunci : e-learning, moodle, pembelajaran matematika, PGSD.

\begin{abstract}
Abstrack
The limited lecture time in class sometimes prevents lecturers from providing all lecture material, this difficulty is often complained of by students. For this reason, e-learning courses on elementary mathematics learning based on moodle applications are developed that can provide learning experiences for students as an actualization of student centered learning. The purpose of this research is to produce e-learning courses in elementary mathematics learning based on moodle applications in a valid, practical, and effective PGSD study program. The type of research used is development research with the Plomp development model, which consists of three stages: preliminary research, prototyping phase, and assessment phase. The research data were obtained from tests of validity, practicality, and effectiveness. Validity test data is obtained through validation sheets. Practicality data was obtained from student response questionnaire sheets, and interviews. The effectiveness data can be seen from the activities and student learning outcomes. The results showed that the developed e-learning met the valid criteria in terms of content and construct with an average value of $95 \%$. E-learning has been practical both in terms of implementation, convenience, and time required with an average value of $92.5 \%$. E-learning has also been effective in terms of student learning activities and outcomes with an average value of $81.2 \%$ activity and learning outcomes with a mastery level of $87.5 \%$. Based on these results it can be concluded that the development e-learning can be declared valid, practical, and effective.
\end{abstract}

Keywords : e-learning, moodle, mathematics learning, PGSD

@ Jurnal Basicedu Prodi PGSD FIP UPTT 2019

$\triangle$ Corresponding author :

Address :

Email :

ISSN 2580-3735 (Media Cetak)

Phone : 


\section{PENDAHULUAN}

Di era revolusi industri 4.0 atau inovasi disruptif ini, manusia dapat mempelajari suatu hal dengan sangat mudah dari mana saja. Terbatasnya waktu belajar mengajar di dalam kelas terkadang menghalangi para dosen atau tenaga pendidik dalam memberikan semua materi pelajaran kepada anak didiknya. Hal ini menjadi masalah tersendiri untuk tenaga pendidik yang ingin menyampaikan materi pelajaran atau kuliahnya secara detail. Kesulitan ini banyak dikeluhkan oleh mahasiswa dan dosen saat ini, yang terkadang memiliki materi yang butuh penjelasan dalam waktu lama justru harus dijelaskan pada waktu singkat. Selain itu dosen atau tenaga pendidik juga terkendala dalam memberikan soal-soal latihan ataupun ulangan secara manual berikut pengkoreksian hasilnya.

Perkembangan teknologi informasi dan komunikasi yang semakin pesat, khususnya internet, memungkinkan pengembangan layanan informasi yang lebih baik dalam suatu institusi pendidikan. Seiring dengan kebutuhan akan metode dan konsep pembelajaran yang lebih efektif dan efisien, pemanfaatan teknologi informasi untuk pendidikan menjadi tidak terelakkan lagi. Pembelajaran daring (online) adalah suatu kemajuan penting dalam sistem pendidikan modern. Pembelajaran daring juga sering dipahami sebagai suatu bentuk pembelajaran berbasis web yang dapat diakses pada jaringan komputer, baik berbentuk intranet maupun internet. Saat ini pembelajaran daring telah dimanfaatkan dalam berbagai model pembelajaran yang berbasis Teknologi Infomasi dan Komunikasi, salah satu contohnya adalah pembelajaran daring berbasis software Modular Object-Oriented Dynamic Learning Environment (Moodle).

Salah satu mata kuliah yang wajib diikuti mahasiswa Pendidikan Guru Sekolah Dasar adalah mengembangkan pembelajaran matematika SD. Pembelajaran matematika SD merupakan mata kuliah yang penting bagi mahasiswa PGSD sebagai calon guru SD. Mahasiswa diberi kesempatan untuk belajar dan praktik dalam pembelajaran matematika di SD. Pembelajaran daring (online) mata kuliah pembelajaran matematika SD diharapkan dapat memberikan mahasiswa pengalaman belajar sebagai aktualisasi dari SCL (Student Centered Learning) dengan baik dan benar. Materi pembelajaran (resources) dalam format digital atau dalam bentuk file. Materi pembelajaran dapat berupa dokumen, presentasi, gambar, video, link, URL, audio, dan animasi. Sumber belajar ini perlu diorganisir sesuai sedemikian rupa sehingga mudah ditemukan dan digunakan pada saat pengembangan sistem pembelajaran daring (online) pada mata kuliah pembelajaran matematika di SD.

Pemanfaatan e-learning dalam proses pembelajaran diharapkan bisa meningkatkan motivasi dan hasil belajar peserta didik. Selain itu, alur proses pembelajaran tidak harus berasal dari guru menuju peserta didik. Peserta didik bisa juga saling belajar dari sesama peserta didik lainnya. Prestasi belajar yang tinggi dapat diraih berkat sinergi dari semua komponen yang membangun pembelajaran itu sendiri, menurut Gulo (2002) komponen belajar mengajar terdiri dari tujuan pengajaran, guru, dosen, mahasiswa, peserta didik, materi pelajaran, metode pengajaran, media pengajaran, serta faktor administrasi dan finansial.Keberhasilan belajar dipengaruhi oleh banyak faktor, secara garis besar faktor-faktor yang mempengaruhi keberhasilan belajar itu dapat dibagi menjadi dua bagian besar yaitu faktor internal dan faktor eksternal (Hakim, 2005).

Hasil observasi yang dilakukan menunjukkan bahwa mata kuliah pembelajaran matematika SD baru mulai efektif diajarkan pada 
semester ganjil Tahun Akademik 2018/2019 pada semester V di Program Studi PGSD sehingga masih diperlukan sumber-sumber belajar pemanfaatan internet. Adanya hotspot area di perguruan tinggi ini juga sangat memungkinkan sekali untuk pengembangan proses belajar mengajar menggunakan pemanfaatan internet, baik di kampus maupun saat para mahasiswa berada di rumah. Pemanfaatan internet sebagai sumber belajar belum maksimal, baik oleh dosen maupun mahasiswa.

Pemanfaatan e-learning dalam mata kuliah pembelajaran matematika merupakan sebuah terobosan yang diharapkan mampu menambah motivasi mahasiswa untuk belajar karena dalam e-learning ada interaksi langsung mahasiswa dengan materi, penugasan, dan evaluasi.Interaksi langsung ini merupakan aktifitas belajar yang aktif dari mahasiswa, sehingga dosen dalam pembelajaran berfungsi sebagai fasilitator saja. Dosen yang profesional lebih mengedepankan kualitas pengajaran daripada materiil oriented (Djamarah, 2008). Guru sebagai fasilitator berperan bukan semata-mata memberikan informasi, melainkan juga mengarahkan dan memberi fasilitas belajar (directingand facilitating the learning) agar proses belajar lebih memadai (Sagala, 2008).

Berdasarkan latar belakang masalah di atas maka peneliti tertarik mengembangkan mata kuliah pembelajaran matematika SD berbasis aplikasi moodle di program Studi PGSD STKIP PGRI Lubuklinggau yang diharapkan dapat memfasilitasi mahasiswa dalam proses perkulihan dengan memanfaatkan internet. Hal ini diharapkan dapat memberikan mahasiswa pengalaman belajar sebagai aktualisasi dari SCL (Student Centered Learning) dengan baik dan benar.

\section{METODE}

Penelitian ini merupakan jenis penelitian desain (Design Research). Penelitian ini dilaksanakan dengan tujuan untuk mengembangkan dan menghasilkan sebuah produk sebagai suatu pemecahan masalah yang ada di dunia pendidikan. Produk yang akan dihasilkan dalam peneltian ini yaitu e-learning mata kuliah pembelajaran matematika di SD berbasis aplikasi moodle pada mahasiswa semester V Prodi S1 PGSD STKIP PGRI Lubuklinggau tahun akademik 2019/2020.

Penelitian ini menggunakan model pengembangan yang diadaptasi dari model yang dikembangkan oleh Plomp yang disebut sebagai model penelitian. Model Plomp terdiri dari tiga tahapan yaitu: preliminary research, prototyping phase, dan assesment phase. Data penelitian diperoleh dari uji validitas, praktikalitas, dan efektivitas. Data uji validitas diperoleh melalui lembar validasi perangkat pembelajaran. Data kepraktisan diperoleh dari lembar angket respon mahasiswa, dan wawancara mahasiswa. Data keefektifan dilihat dari aktivitas mahasiswa dan hasil belajar mahasiswa. Data yang telah dikumpulkan selanjutnya dianalisis secara deskriptif.

\section{HASIL DAN PEMBAHASAN}

Setelah melakukan analisis pendahuluan, merancang prototipe dan memvalidasi e-learning mata kuliah pembelajaran matematika SD berbasis aplikasi moodle, hasil penelitian dan diskusi disajikan sebagai berikut.

Tahap analisis pendahuluan dilakukan sebelum mengembangkan dan merancang produk. Pada tahap ini dilakukan identifikasi masalah dan kebutuhan dalam pelaksanaan perkuliahan di STKIP PGRI Lubuklinggau. Berikut ini dipaparkan hasil dari analisis yang dilakukan pada tahap analisis pendahuluan. Hasil analisis RPS 


\section{Pengembangan e-learning mata kuliah pembelajaran matematika SD berbasis aplikasi moodle di PGSD-Akmal Rijal, Andriana Sofiarini}

dijabarkan menjadi deskripsi mata kuliah yaitu untuk menguasai berbagai kemampuan dan keterampilan mengajarkan materi-materi pelajaran matematika sekolah dasar, yang berhubungan dengan bangun datar (titik, garis, bidang, sudut, segi banyak, lingkaran simetri, pengubinan, dan bidang koordinat), bangun ruang (bidang banyak, bangun tiga dimensi berpermukaan lengung), pecahan, perbandingan, persen, desimal, skala, bilangan (konsep, operasi hitung, dan sifatsifatnya), pengukuran (panjang, keliling, luas, volume, berat, kapasitas, dan sudut), dan pengelolaan data (jenis, mendapatkan, mengolah, menyajikan data, ukuran gejala pusat, luas, volume). Isi kurikulum tersebut dinilai sudah baik untuk mencapai tujuan pembelajaran sehingga tidak dilakukan perubahan urutan materi karena telah menjabarkan materi yang sesuai dalam mengembangkan isi e-learning mata kuliah pembelajaran matematika SD berbasis aplikasi moodle. Hasil analisis kurikulum inilah yang dijadikan sebagai pertimbangan untuk membuat $e$ learning mata kuliah pembelajaran matematika SD berbasis aplikasi moodle.

Analisis konsep merupakan identifikasi materi-materi pokok yang akan dibahas pada pembelajaran. Analisis konsep bertujuan untuk menyusun urutan materi yang akan dibahas. Pada hasil perumusan capaian mata kuliah pembelajaran matematika SD. Materi disusun secara sistematis dengan menggunakan peta konsep sehingga materi yang akan dibahas dapat dilihat dengan spesifik. Materi bilangan dan operasi hitung, materi bilangan kelipatan dan faktor serta KPK dan FPB, dan materi pecahan. Menguasai materi-materi, mengajarkan materi, membuat media pembelajaran dan menyelesaikan masalah yang berkaitan dengan materi, materi sudah terurut dengan baik.

Hasil analisis karakteristik mahasiswa yang dilakukan adalah usia mahasiswa semester $\mathrm{V}$ program studi PGSD STKIP PGRI Lubuklinggau. mahasiswa berada pada usia 18-22 tahun. Kemampuan mahasiswa semeter $\mathrm{V}$ ini rata-rata sedang berdasarkan hasil wawancara dengan dosen, hal ini disimpulkan dari rata-rata nilai. Karakteristik mahasiswa semester V program studi PGSD STKIP PGRI Lubuklinggau yaitu mereka senang dengan sesuatu hal yang baru dan menarik, memiliki rasa ingin tahu yang tinggi terhadap hal yang baru. Selain itu, karakteristik mahasiswa di sekolah ini juga menunjukkan menyukai kerjasama dan TIK. Sebagai buktinya adalah ketika diberikan tugas kuliah, mahasiswa memiliki keinginan yang lebih besar untuk mencari tugas dari internet dibandingkan dari buku ajar cetak. Berdasarkan deskripsi di atas, terlihatlah bahwa karakteristik mahasiswa semester $\mathrm{V}$ program studi PGSD STKIP PGRI Lubuklinggau adalah memiliki rasa ingin tahu yang cukup tinggi, senang dengan sesuatu hal yang baru dan menarik, serta menyukai TIK, atas dasar karakteristik mahasiswa yang demikian, maka dilakukan penelitian yang menghadirkan sarana belajar yang berbeda dari yang digunakan sebelumnya, yaitu pembelajaran daring dengan internet, serta mengembangkan rasa ingin tahu kearah yang positif, yang erat kaitannya dengan perkembangan proses berpikir mahasiswa.

Analisis tempat penelitian dilakukan dengan cara menngamati proses perkuliahan selama ini yang dilaksanakan di program studi PGSD STKIP PGRI Lubuklinggau pada perkuliahan yang dilaksankan dosen. Hasil analisis tempat penelitian yang dilaksanakan di lapangan terlihat bahwa mahasiswa jarang diajak untuk memanfaatkan inovasi TIK dan internet dalam proses perkuliahan. Mata kuliah pembelajaran matematika SD baru mulai efektif diajarkan pada semester ganjil Tahun Akademik 2018/2019 pada semester V di Program Studi PGSD sehingga masih diperlukan sumber-sumber belajar pemanfaatan internet. Adanya hotspot area di perguruan tinggi ini juga sangat memungkinkan 
sekali untuk pengembangan proses belajar mengajar menggunakan pemanfaatan internet, baik di kampus maupun saat para mahasiswa berada di rumah. Pemanfaatan internet sebagai sumber belajar belum maksimal, baik oleh dosen maupun mahasiswa. Hasil analisis tempat penelitian ini yang dijadikan sebagai pertimbangan untuk membuat e-learning mata kuliah pembelajaran matematika SD berbasis aplikasi moodle yang diharapkan dapat memberikan mahasiswa pengalaman belajar sebagai aktualisasi dari SCL (Student Centered Learning) dengan baik dan benar.

Hasil rancangan prototipe awal ini diberi nama prototipe 1. Berikut ini akan diuraikan karakteristik e-learning mata kuliah pembelajaran matematika SD berbasis aplikasi moodle yang telah dirancang. Karakteristik e-learning yang dikembangkan yaitu sebagai berikut.

E-learning mata kuliah pembelajaran matematika SD berbasis aplikasi moodle diperlukan untuk memudahkan dosen dalam menyajikan materi perkuliahan dan memudahkan peserta didik untuk berinteraksi dengan materi pembelajaran, mengkonstruksi materi baru bagi orang lain, dan berinteraksi dengan para siswa lain tentang materi itu.menyerap informasi dalam proses pembelajaran. e-learning mata kuliah pembelajaran matematika SD berbasis aplikasi moodle yang dikembangkan mengacu pada indikator-indikator yang telah dirumuskan sebelumnya. Penyajian e-learning mata kuliah pembelajaran matematika SD berbasis aplikasi moodle dalam bentuk web, diproses dengan menggunakan platform aplikasi moodle 3.4 yang dapat di download langsung di situsnya : https://moodle.org dan pada materi bilangan, kelipatan dan faktor FPB dan KPK, dan pecahan.

Sebelum menginstal moodle, kita diharuskan menginstal aplikasi web server terlebih dahulu, dalam hal ini kita memakai XAMPP. Fungsinya adalah sebagai server yang berdiri sendiri (localhost), yang terdiri atas program Apache HTTP Server, MySQL database, dan penerjemah bahasa yang ditulis dengan bahasa pemrograman PHP dan Perl. Nama XAMPP merupakan singkatan dari $\mathrm{X}$ (empat sistem operasi apapun), Apache, MySQL, PHP dan Perl. Program ini tersedia dalam GNU (General Public License) dan bebas, merupakan web server yang mudah digunakan yang dapat melayani tampilan halaman web yang dinamis. Untuk mendapatkanya dapat mengunduh langsung dari web resminya di http://www.apachefriends.org. Untuk dapat membangun suatu portal e-learning diperlukan tempat atau server di internet dan nama domain atau alamat (URL). Server berfungsi sebagai tempat untuk menaruh file-file dan aplikasi $e$ learning sehingga dapat diakses melalui internet dengan alamat tertentu (URL). Oleh karena itu kita harus mengusahakan dua hal tersebut, yakni webhosting dan nama domain. Ada banyak penyedia webhosting di internet yang bisa kita peroleh baik secara gratis maupun membayar. Sedangkan nama domain yang akan menjadi alamat (URL) dapat juga kita sewa melalui penyedia tersebut. Namun biasanya bila kita mendaftar webhosting secara gratis, maka nama domain sudah diberikan dan kita tidak harus menyewa sendiri. Adapun domain dan webhosting yang digunakan yaitu gnomio.com yang dapat di download langsung di http://www.gnomio.com. Setelah dilakukan instalasi e-learning situs web $e$ learning telah berhasil dijalankan dan dapat diakses

https://elearningpgsdstkippgrillg.gnomio.com/.

E-learning yang telah dirancang dievaluasi dengan instrumen self evaluation e-learning. Setelah dilakukan evaluasi maka perangkat pembelajaran direvisi. Revisi dilakukan pada $e$ learning yaitu kesalahan-kesalahan dalam pengetikan e-learning. E-learning mata kuliah 
pembelajaran matematika SD berbasis aplikasi moodle selanjutnya didiskusikan dengan rekan penelitian. Kemudian e-learning divalidasi oleh validator. Dosen yang menjadi validator berasal dari 3 bidang keahlian yaitu materi, media, dan desain. persentase rata-rata skor penilaian $e$ learning mata kuliah pembelajaran matematika SD berbasis aplikasi moodle yang diperoleh dari 3 kriteria yaitu (1) aspek materi dengan kategori sangat valid, (2) aspek desain dengan kategori sangat valid, dan (3) aspek media dengan kategori sangat valid. Ketiga kriteria data yang disajikan dapat disimpulkan bahwa rata-rata validasi $e$ learning mata kuliah pembelajaran matematika SD berbasis aplikasi moodle secara keseluruhan adalah 95\% dengan kategori sangat valid yang dapat dilihat pada tebel 1. E-learning mata kuliah pembelajaran matematika SD berbasis aplikasi moodle telah dinyatakan dapat dilanjutkan pada uji praktikalitas.

Tabel 1. Hasil validasi e-learning

\begin{tabular}{|l|l|l|l|}
\hline No. & Validator & $\begin{array}{l}\text { Rata-rata } \\
(\boldsymbol{\%})\end{array}$ & Kategori \\
\hline 1. & $\begin{array}{l}\text { Validator I } \\
\text { (materi) }\end{array}$ & 96 & $\begin{array}{l}\text { Sangat } \\
\text { valid }\end{array}$ \\
\hline 2. & $\begin{array}{l}\text { Validator II } \\
\text { (desain) }\end{array}$ & 94 & $\begin{array}{l}\text { Sangat } \\
\text { valid }\end{array}$ \\
\hline 3. & $\begin{array}{l}\text { Validator III } \\
\text { (media) }\end{array}$ & 94 & $\begin{array}{l}\text { Sangat } \\
\text { valid }\end{array}$ \\
\hline & Rata-rata & 95 & $\begin{array}{l}\text { Sangat } \\
\text { Valid }\end{array}$ \\
\hline
\end{tabular}

One to one evaluation dilakukan dengan meminta mahasiswa menggunakan e-learning mata kuliah pembelajaran matematika SD berbasis aplikasi moodle (Prototype 2). One to one evaluation ini dilakukan sebanyak satu kali pertemuan, yaitu pada tanggal 30 Agustus 2019 di PGSD STKIP PGRI Lubuklinggau. Mahasiswa diminta untuk mengakses e-learning yaitu kepada dua orang mahasiswa dengan kemampuan mereka masing-masing. Setelah mahasiswa mengerjakan e-learning, mahasiswa diberikan angket respon mahasiswa dan lembar wawancara repon mahasiswa. rata-rata praktikalitas e-learning mata kuliah pembelajaran matematika SD berbasis aplikasi moodle pada tahap one to one evaluation adalah 99\% dengan kategori sangat praktis. Hasil wawancara mahasiswa menyatakan tertarik belajar dengan e-learning mata kuliah pembelajaran matematika SD berbasis aplikasi moodle yang telah dirancang karena kegiatannya menarik dan mudah digunakan. Mahasiswa juga menyatakan memahami materi yang ada dalam e-learning dan tidak terlalu banyak membutuhkan arahan untuk menyelesaikan setiap kegiatan perkuliahan.

Prototipe 3 juga dievaluasi untuk melihat kepraktisannya. Evaluasi dilakukan dengan cara melakukan small group discussion atau evaluasi kelompok kecil pada tanggal 30 Agustus 2019 di PGSD STKIP PGRI Lubuklinggau dengan mencoba e-learning mata kuliah pembelajaran matematika SD berbasis aplikasi moodle yang telah dirancang kepada mahasiswa dengan empat orang mahasiswa yang berasal dari kemampuan tinggi, sedang, dan rendah. Untuk menilai kepraktisan e-learning juga menggunakan angket respon mahasiswa dan lembar pedoman wawancara. rata-rata praktikalitas e-learning mata kuliah pembelajaran matematika SD berbasis aplikasi moodle pada tahap small group adalah 96\% dengan kategori sangat praktis. Hasil wawancara mahasiswa menyatakan tertarik belajar dengan e-learning yang telah dirancang karena kegiatannya menarik, praktis, mudah dan jelas. Mahaiswa juga menyatakan memahami materi yang ada dalam e-learning dan tidak terlalu banyak membutuhkan arahan untuk menyelesaikan setiap kegiatan perkuliahan.

Setelah dilakukan revisi, selanjutnya $e$ learning mata kuliah pembelajaran matematika SD berbasis aplikasi moodle diujicobakan di kelas pada perkuliahan pembelajaran matematika SD di program studi PGSD STKIP PGRI Lubuklinggau 
semester V angkatan 2017 dengan jumlah mahasiswa sebanyak 33 orang. Field test dilakukan pada tanggal 09 September 2019 dengan cara meminta mahasiswa mempraktekkan perkuliahan dengan e-learning mata kuliah pembelajaran matematika SD berbasis aplikasi moodle yang telah dirancang pada materi kelipatan dan faktor dan FPB dan KPK. Data hasil uji coba yang diperoleh, diuraikan sebagai berikut. rata-rata tingkat kepraktisan e-learning mata kuliah pembelajaran matematika SD berbasis aplikasi moodle menurut respon mahasiswa adalah 92,5\%. Hasil rekapitulasi angket respon mahasiswa dapat dilihat pada tabel 2 berikut.

Tabel 2. Hasil praktikalitas e-learning

\begin{tabular}{|l|l|l|l|}
\hline No. & Tahap & $\begin{array}{l}\text { Rata-rata } \\
(\boldsymbol{\%})\end{array}$ & Kategori \\
\hline 1. & $\begin{array}{l}\text { One to one } \\
\text { evaluation }\end{array}$ & 99 & $\begin{array}{l}\text { Sangat } \\
\text { praktis }\end{array}$ \\
\hline 2. & Small group & 96 & $\begin{array}{l}\text { Sangat } \\
\text { praktis }\end{array}$ \\
\hline 3. & Field test & 92.5 & $\begin{array}{l}\text { Sangat } \\
\text { praktis }\end{array}$ \\
\hline & Rata-rata & 95.83 & $\begin{array}{l}\text { Sangat } \\
\text { Praktis }\end{array}$ \\
\hline
\end{tabular}

Berdasarkan tabel 2, dapat disimpulkan bahwa e-learning mata kuliah pembelajaran matematika SD berbasis aplikasi moodle dinyatakan sangat praktis. Secara keseluruhan berdasarkan hasil observasi pembelajaran pada aktivitas perkuliahan daring (online) dengan $e$ learning ini berjalan dengan lancar, tidak ada kendala berarti yang dihadapi oleh dosen dan mahasiswa. Semua mahasiswa terlihat begitu antusias dan lebih banyak aktif dalam belajar. Berdasarkan hasil wawancara dengan mahasiswa juga ditemukan bahwa rata-rata mahasiswa senang belajar menggunakan e-learning mata kuliah pembelajaran matematika SD berbasis aplikasi moodle karena tampilan yang menarik dan aktivitas perkuliahan yang menyenangkan. Mahasiswa juga merasa tidak membutuhkan banyak arahan dari dosen selama menyelesaikan aktivitas dalam e-learning mata kuliah pembelajaran matematika SD berbasis aplikasi moodle karena petunjuk dan langkah kerja yang diberikan sudah cukup jelas. Selain itu, mahasiswa mengakui ada manfaat yang dirasakannya setelah belajar dengan menggunakan e-learning mata kuliah pembelajaran matematika SD berbasis aplikasi moodle, mahasiswa merasa lebih memahami materi dan dapat mencoba menerapkan konsep yang sesuai dengan materi yang telah dipelajari secara mandiri.

E-learning mata kuliah pembelajaran matematika SD berbasis aplikasi moodle yang sudah dinyatakan praktis, selanjutnya diujicobakan pada mahasiswa semester V PGSD STKIP PGRI Lubuklinggau untuk melihat keefektivannya. Keefektivan e-learning mata kuliah pembelajaran matematika SD berbasis aplikasi moodle dilihat dari aktivitas mahasiswa dan hasil belajar. Nilai rata-rata aktivitas mahasiswa yang diperoleh selama perkuliahan dengan menggunakan $e$ learning mata kuliah pembelajaran matematika SD berbasis aplikasi moodle adalah 81,2\% dengan kategori sangat efektif.

Tabel 3. Hasil aktivitas mahasiswa

\begin{tabular}{|l|l|l|}
\hline No. & Aspek yang diamati & $\begin{array}{l}\text { Persentase } \\
\text { aktivitas }\end{array}$ \\
\hline 1. & Memperhatikan materi & 81 \\
\hline 2. & Memahami aktivitas & 81 \\
\hline 3. & $\begin{array}{l}\text { Mengerjakan langkah- } \\
\text { langkah yang terdapat } \\
\text { dalam e-learning }\end{array}$ & 81 \\
\hline 4 & Mengajukan pertanyaan & 81 \\
\hline 5 & Menanggapi & 82 \\
\hline & Rata-rata & 81.2 \\
\hline
\end{tabular}

Berdasarkan tabel 3 dapat disimpulkan bahwa e-learning mata kuliah pembelajaran matematika SD berbasis aplikasi moodle yang dikembangkan sangat efektif digunakan dalam kegiatan pembelajaran karena dapat meningkatkan aktivitas belajar mahasiswa. Hasil belajar pada 
ranah kognitif diperoleh dari soal tes dalam bentuk soal isian. Tes dilakukan setelah selesai pembelajaran menggunakan soal tes formatif yang ada di e-learning mata kuliah pembelajaran matematika SD berbasis aplikasi moodle kemudian diujicobakan kepada mahasiswa semester V PGSD STKIP PGRI Lubuklinggau. Perolehan nilai yang didapat dari 33 orang mahasiswa yang mengerjakan soal tes untuk menilai efektivitas mahasiswa semester V PGSD STKIP PGRI Lubuklinggau dari ranah kognitif. Rata-rata ketuntasan klasikal yang diperoleh adalah 87,5\%. Hasil akhir yang didapatkan tersebut telah sesuai dengan tujuan yang telah ditetapkan yaitu $385 \%$ peserta didik tuntas belajarnya, sehingga apabila dilihat secara klasikal hasil belajar ranah kognitif dengan menggunakan mahasiswa semester $\mathrm{V}$ PGSD STKIP PGRI Lubuklinggau telah dikatakan tuntas.

Pembahasan

Penelitian ini merupakan penelitian pendidikan dengan model design research yang mengembangkan suatu produk. Model pengembangan yang digunakan dalam penelitian ini diadaptasi dari model McKenny. Model ini terdiri atas 3 tahap, yaitu (1) preliminary research atau analisis pendahuluan, (2) prototyping phase atau tahap perancangan, dan (3) assesment phase atau tahap penilaian (Plomp dan Nieveen, 2013:19). Produk yang dikembangkan dalam penelitian ini adalah e-learning mata kuliah pembelajaran matematika SD berbasis aplikasi moodle. Produk tersebut telah diujicobakan pada mahasiswa semester V PGSD STKIP PGRI Lubuklinggau dengan jumlah mahasiswa 33 orang. Paparan pembahasan mengenai hasil penelitian pengembangan yang telah dilakukan akan diuraikan lebih lanjut terutama yang berkaitan dengan validitas, praktikalitas, dan efektivitas produk yang dikembangkan.
Validitas diperlukan untuk menguji suatu penelitian. Kata "valid" sering diartikan dengan shahih atau absah, menurut Trianto (2011:255), valid artinya penilaian sudah memberikan informasi yang akurat tentang media yang dikembangkan. e-learning mata kuliah pembelajaran matematika SD berbasis aplikasi moodle yang dikembangkan dinyatakan valid apabila telah memenuhi syarat-syarat yang telah ditetapkan baik secara isi maupun konstruk, sesuai dengan pendapat Plomp (2013:29) karakteristik dari produk yang dikatakan valid apabila produk tersebut komponen-komponennya didasarkan pada prinsip pengetahuan, hal inilah yang disebut dengan validitas isi. Selanjutnya, komponenkomponen tersebut juga harus terkait secara konsisten satu sama lain atau disebut juga dengan validitas konstruk. Pada penelitian ini validasi dirinci lagi menjadi validasi produk yang dilakukan terhadap isi, bahasa, penyajian dan kegrafikaan.Validitas e-learning mata kuliah pembelajaran matematika SD berbasis aplikasi moodle melibatkan tiga orang validator, sesuai dengan pendapat Sugiyono (2009:414) bahwa validasi produk dapat dilakukan oleh beberapa pakar atau tenaga ahli yang sudah berpengalaman untuk menilai produk baru yang dirancang, sehingga selanjutnya dapat diketahui kelemahan dan keunggulannya. Hasil validasi dari ahli tersebut dikumpulkan kemudian dianalisis untuk dicari rata-rata dari masing-masing indikator dan masing-masing aspek.

Berdasarkan analisis kevalidan e-learning mata kuliah pembelajaran matematika SD berbasis aplikasi moodle oleh validator dapat disimpulkan secara keseluruhan e-learning mata kuliah pembelajaran matematika SD berbasis aplikasi moodle yang dikembangkan sudah termasuk kategori sangat valid dengan persentase nilai ratarata keseluruhan untuk RPP 95\%. Penilaian yang valid terhadap e-learning mata kuliah 


\section{Pengembangan e-learning mata kuliah pembelajaran matematika SD berbasis aplikasi moodle di PGSD-Akmal Rijal, Andriana Sofiarini}

pembelajaran matematika SD berbasis aplikasi moodle yang dikembangkan menandakan bahwa $e$ learning mata kuliah pembelajaran matematika SD berbasis aplikasi moodle dapat digunakan sebagai model perkuliahan yang berpusat pada peserta didik/mahasiswa bagi dosen di PGSD pada semester lima.

Istilah praktikalitas dalam Kamus Besar Bahasa Indonesia (1990: 698) berarti sesuatu yang bersifat praktis dengan maksud mudah dan senang memakainya. e-learning mata kuliah pembelajaran matematika SD berbasis aplikasi moodle yang telah dinyatakan valid oleh validator selanjutnya diujicobakan untuk melihat praktikalitasnya. Menurut Plomp (2013:29) suatu produk dapat dikatakan praktis apabila dapat digunakan dengan mudah oleh dosen dan mahasiswa sesuai dengan tujuan pengembangan. e-learning mata kuliah pembelajaran matematika SD berbasis aplikasi moodle dikatakan praktis, jika mahasiswa dapat menggunakan e-learning mata kuliah pembelajaran matematika SD berbasis aplikasi moodle tersebut untuk melaksanakan perkuliahan, tanpa banyak masalah.

Uji praktikalitas ini dilakukan untuk mengungkap bagaimana kemudahan penggunaan e-learning mata kuliah pembelajaran matematika SD berbasis aplikasi moodle, kesesuaian waktu dengan banyak dan bentuk tugas, daya tarik/minat mahasiswa terhadap e-learning mata kuliah pembelajaran matematika SD berbasis aplikasi moodle dan keterbacaan e-learning mata kuliah pembelajaran matematika SD berbasis aplikasi moodle oleh mahasiswa.

Uji praktikalitas dilakukan melalui beberapa kegiatan, yaitu one to one evaluation, small group dan field test. Setelah mendapatkan saran dari ahli, produk kemudian dilakukan revisi sesuai dengan saran. Selanjutnya, produk diujicobakan pada mahasiswa melalui uji one to one evaluation. Uji one to one evaluation dilakukan terhadap dua orang mahasiswa semester V PGSD STKIP PGRI Lubuklinggau dengan kemampuan akademik yang berbeda. Hasil analisis angket praktikalitas mahasiswa diperoleh nilai rata-rata 96\% dengan kategori sangat praktis. Hasil wawancara dengan mahasiswa juga menunjukkan bahwa mahasiswa menyatakan sangat menarik karena dilengkapi dengan aktivitas-aktivitas yang menarik dan memotivasi belajar bagi mahasiswa. Tampilan e-learning mata kuliah pembelajaran matematika SD berbasis aplikasi moodle juga sudah menarik, sehingga mahasiswa lebih bersemangat untuk mempelajari materi. Selain itu, mahasiswa juga menyatakan tidak terlalu banyak membutuhkan arahan selama menyelesaikan setiap aktivitas pada e-learning mata kuliah pembelajaran matematika SD berbasis aplikasi moodle. Meskipun demikian, ada beberapa bagian dari $e$ learning tersebut yang membuat mahasiswa kebingungan yaitu penggunaan huruf terlalu keil. Oleh sebab itu, dilakukan sedikit perbaikan pada $e$ learning. Hal ini sesuai dengan hasil penelitian yang telah dilakukan oleh Leli Tuti Suharni (2019:982) dengan judul "pengembangan desain pembelajaran dengan model assure di sekolah dasar". Penelitian tersebut mengembangkan model desain pembelajaran ASSURE memenuhi aspek kepraktisan baik ditinjau dari respon pendidik dan peserta didik.

Hasil penelitian menunjukkan bahwa model desain pembelajaran ASSURE menunjukkan bahwa desain pembelajaran yang dikembangkan berada pada kategori sangat valid. Berdasarkan hasil uji coba yang akan dilakukan, diperoleh bahwa desain pembelajaran diharapkan memenuhi aspek kepraktisan ditinjau dari respon pendidik dan peserta didik. Desain pembelajaran ini juga diharapkan memenuhi aspek keefektifan yang dilihat dari: 1) aktivitas peserta didik; 2) sikap; 3) pengetahuan peserta didik yang diharapkan melampaui KKM; 4) keterampilan 
peserta didik. Desain pembelajaran yang dikembangkan berupa RPP memiliki karakteristik: 1) praktis dalam penggunaan dan 2) menggunakan bahasa yang jelas, logis, dan sistematis.

Istilah efektivitas dalam Kamus Besar Bahasa Indonesia (1990: 219) berarti efek, akibat, pengaruh, kesannya. Jadi, efektivitas artinya dampak, pengaruh, dan hasil yang ditimbulkan dari suatu tindakan dalam hal ini terhadap penggunaan e-learning mata kuliah pembelajaran matematika SD berbasis aplikasi moodle. $e$ learning mata kuliah pembelajaran matematika SD berbasis aplikasi moodle dapat dikatakan efektif jika memberikan dampak yang baik terhadap aktivitas dan perkembangan kognitif mahasiswa. Efektivitas dapat dilakukan apabila e-learning sudah dinyatakan valid dan praktis. Efektivitas $e$ learning mata kuliah pembelajaran matematika SD berbasis aplikasi moodle yang dikembangkan dapat dilihat dari aktivitas dan hasil belajar mahasiswa.

Hasil analisis aktivitas mahasiswa secara keseluruhan selama proses pembelajaran menunjukkan bahwa aktivitas mahasiswa berada dalam kategori sangat efektif dengan nilai rata-rata $81,2 \%$. Dari 33 orang mahasiswa yang telah mengikuti pembelajaran dengan menggunakan $e$ learning mata kuliah pembelajaran matematika SD berbasis aplikasi moodle. Terlihat bahwa mahasiswa umumnya melakukan aktivitas pembelajaran yang cukup bervariasi. Sejalan dengan pendapat Hollingsworth dan Lewis (2008:8) bahwa peserta mahasiswa secara aktif ketika mereka terlibat secara terus menerus, baik mental maupun fisik. Pembelajaran aktif melibatkan pembelajaran yang terjadi ketika mahasiswa bersemangat siap secara mental, dan bisa memahami pengalaman yang dialami

Berdasarkan data aktivitas mahasiswa dari 33 orang mahasiswa yang telah mengikuti pembelajaran dengan menggunakan e-learning mata kuliah pembelajaran matematika SD berbasis aplikasi moodle, terlihat bahwa semua aktivitas sangat menonjol yaitu ketertarikan mahasiswa dengan persentase rata-rata hampir $81,2 \%$. Ketertarikan mahasiswa pada aktivitas ini disebabkan karena adanya kegiatan-kegiatan yang menyenangkan serta tampilan e-learning mata kuliah pembelajaran matematika SD berbasis aplikasi moodle yang dapat menarik minat belajar mahasiswa.

Hasil belajar mahasiswa diperoleh melalui soal evaluasi yang ada di e-learning mata kuliah pembelajaran matematika SD berbasis aplikasi moodle yang terdiri dari 5 soal isian. Berdasarkan analisis data hasil tes akhir didapat nilai rata-rata peserta didik 87,5\%. Dengan demikian e-learning mata kuliah pembelajaran matematika SD berbasis aplikasi moodle sudah bisa dikatakan efektif. Hasil penelitian yang dilakukan oleh Novri Yaldi (2019:993) juga menyatakan bahwa "nilai persentase dihasilkan dari aktivitas saat penelitian dan penyebaran serta hasil belajar saat penelitian dan penyebaran". Hasil penelitian tersebut menunjukkan bahwa hasil efektivitas yang diperoleh dari aktivitas berpikir kritis dan hasil belajar yang diperoleh Nilai persentase dihasilkan dari aktivitas saat penelitian dan penyebaran serta hasil belajar saat penelitian dan penyebaran dengan kategori sangat efektif. Dengan demikian dapat disimpulkan bahwa pembelajaran dengan menggunakan e-learning mata kuliah pembelajaran matematika SD berbasis aplikasi moodle sangat efektif digunakan dalam pembelajaran karena dapat meningkatkan hasil belajar mahasiswa.

\section{SIMPULAN}

Penelitian ini merupakan penelitian pengembangan yang menghasilkan e-learning mata kuliah pembelajaran matematika SD berbasis aplikasi moodle. Berdasarkan hasil pengembangan 
dan uji coba e-learning mata kuliah pembelajaran matematika SD berbasis aplikasi moodle diperoleh kesimpulan sebagai berikut.

1. Telah dihasilkan e-learning mata kuliah pembelajaran matematika SD berbasis aplikasi moodle dengan kategori rata-rata hasil validasi keseluruhan $95 \%$ dengan kategori sangat valid, berdasarkan hasil validasi perangkat pembelajaran oleh validator ahli. Hasil yang didapat memberi gambaran bahwa e-learning mata kuliah pembelajaran matematika SD berbasis aplikasi moodle yang dikembangkan telah valid dan dapat digunakan dalam perkuliahan.

2. Praktikalitas e-learning mata kuliah pembelajaran matematika SD berbasis aplikasi moodle secara keseluruhan sangat praktis. Praktikalitas perangkat pembelajaran matematika diketahui dari hasil angket respon mahasiswa yang telah mengikuti pembelajaran dengan menggunakan e-learning mata kuliah pembelajaran matematika SD berbasis aplikasi moodle dengan rata-rata 92,5\% dan wawancara mahasiswa yang tertarik mengajar dan belajar menggunakan e-learning mata kuliah pembelajaran matematika SD berbasis aplikasi moodle. Hasil ini memberi gambaran bahwa penggunaan e-learning mata kuliah pembelajaran matematika SD berbasis aplikasi moodle mahasiswa sangat praktis dan dapat membantu meningkatkan minat mahasiswa dalam perkuliahan.

3. Efektivitas penggunaan e-learning mata kuliah pembelajaran matematika SD berbasis aplikasi moodle dapat diketahui melalui pengamatan aktivitas belajar mahasiswa, dan hasil belajar mahasiswa. Aktivitas e-learning mata kuliah pembelajaran matematika SD berbasis aplikasi moodle selama belajar dengan menggunakan e-learning mata kuliah pembelajaran matematika SD berbasis aplikasi moodle ini sangat efektif dengan rata-rata $80 \%$ dan hasil belajar siswa dengan rata-rata 87,5\%. Hasil pengamatan ini memberi gambaran bahwa penggunaan e-learning mata kuliah pembelajaran matematika SD berbasis aplikasi moodle sudah efektif dilaksanakan.

\section{DAFTAR PUSTAKA}

Aditra Pradnyana, 2015, Implementasi Responsive E-learning Berbasis MOODLE Untuk Menunjang Kegiatan Pembelajaran di STMIK STIKOM Indonesia, Jurnal S@CIES Volume 5, Nomor 2, April 2015, hlm 127-135.

Amir., 2014. Pembelajaran Matematika SD, Forum Paedagogik Vol. VI, No.01 Jan 2014.

Anang Setiyo W, 2013, Perancangan E-learning dengan Menggunakan Learning Management System (LMS), Widya Warta No. 02 Tahun XXXV II/ Juli 2013 ISSN 0854-1981.

Anita Ratnasari, 2012, Studi Pengaruh Penerapan E-learning Terhadap Keaktifan Mahasiswa dalam Kegiatan Belajar Mengajar Studi Kasus Universitas Mercu Buana Jakarta, Seminar Nasional Aplikasi Teknologi Informasi 2012 (SNATI2012) ISSN:1907-5022 Yogyakarta,15-16 Juni 2012.

Cole, J. 2005 Using Moodle: Teaching with the Popular Open Source Course Management System. O'Reily Media Inc. California.

Depdiknas. 2006. Panduan Penyusunan Kurikulum Tingkat Satuan Pendidikan. Jakarta: Depdiknas.

Depdiknas. 2008. Pengembangan LKS. Jakarta: Departemen Pendidikan Nasional.

Effendy E \& H Zhuang. 2005. e-learning Konsep dan Aplikasi. Yogyakarta: Penerbit Andi.

E-learning characteristics; http://www.mwcomputing.com diakses 30 Juni 2018. 
2082 Pengembangan e-learning mata kuliah pembelajaran matematika SD berbasis aplikasi moodle di PGSD-Akmal Rijal, Andriana Sofiarini

Eliza F. 2014. Pemanfaatan e-learning dalam proses pembelajaran di jurusan teknik elektro FT UNP. Jurnal Teknologi Informasi \& Pendidikan 5 (2):91-101.

Ergin, I. 2012. Constructivist Approach Based 7E Model And Usability Instructional Math. Turkish Military Academi. Turky. Journal Math Education 6 (1) 2012 online at http//www.lajpe.org. [diakses tanggal 7 April 2018].

Erviyana, G. 2012. Pengembangan LKS matematika Dengan learning cycle $7 E$ pada untuk Kelas $V$ di SD Negeri 7 Malang. Jurnal matematika Volume 4 No. 2 Juni 2014.

Hamalik, O. 2008. Proses Belajar Mengajar. Jakarta: PT. Bumi Aksara.

Leli, T. (2019). Pengembangan desain pembelajaran dengan model assure di sekolah dasar. Jurnal Basicedu, Vol. 3 No.3, 976-982.

LMS

Moodle;

Http://blog.uny.ac.id/hermansurjono, diakses 30 Juni 2018.

Mulyasa, E. 2009. Implementasi Kurikulum Tingkat Satuan Pendidikan Kemandirian Guru dan Kepala Sekolah. Jakarta: Bumi Aksara.

Novri, Y. (2019). Pengembangan LKS learning cycle $7 \mathrm{e}$ dalam meningkatkan berpikir kritis siswa di sekolah dasar. Jurnal Basicedu, Vol. 3 No.3, 990-993.

Nurkhamid 2008. Mengelola E-learning dengan Moodle. Yogyakarta : Jurusan Elektronika, Fakultas Teknik, UNY.

Plomp, Tj. (2013). Educational Design: Introduction. From Tjeerd Plomp (eds). Educational \&Training System Design: Introduction. Design of Education and Training (in Dutch).Utrecht (the Netherlands): Lemma. Netherland. Faculty of Educational Science andTechnology, University of Twente.

Prastowo A. 2011. Panduan Kreatif Membuat LKS Inovatif. Yogyakarta: Diva Press.

Purwanto, D. 2014. Pengembangan Perangkat Pembelajaran (Silabus, RPP, PHB, Perangkat pembelajaran). Yogyakarta: Gava Media.

Rice, H.W. 2006 Moodle: Elearning Course Development. Pack Publishing. Birmingham. Mumbai.
Riduwan \& Sunarto. 2012. Pengantar Statistika. Bandung: Alfabeta.

Sanjaya, Wina. 2009. Perencanaan dan Desain Sistem Pembelajaran. Jakarta: Prenada Media Group.

Sugiyono. 2011. Metode Penelitian Kuantitatif Kualitatif dan R\&D. Bandung: Alfabeta.

Tim, 2017, Model Silabus Mata Pelajaran SD/MI. jakarta : Kementerian Pendidikan dan Kebudayaan Republik Indonesia.

Trianto. 2010. Model Pembelajaran Terpadu: Konsep, Strategi dan Implementasinya dalam Kurikulum Satuan Pendidikan (KTSP). Jakarta: Bumi Aksara.

Utari, dkk. 2013. Pengembangan Perangkat Pembelajaran Matematika Dengan learning cycle $7 E$ pada Materi Bangun Ruang untuk Kelas V SDN 02 Bekasi. Tahun Ajaran 2013/2014. Jurnal Matematika Volume 9 No. 2 Juli 2014.

Van den Akker, J. (2014). Principles and Methods of Development Research. Pada J. van den Akker, R.Branch, K. Gustafson, Nieven, dan T. Plomp (eds), Design Approaches and Tools in Education and Training (pp. 1-14). Dortrech: Kluwer Academic Publishers.

Moodle Documentations. http://docs.moodle.org/ (Akses terakhir April2007). 